\title{
Perluasan notasi Dewey Decimal Classification (DDC) tentang bahasa dan susastra Sunda
}

\author{
Asep Saeful Rohman'1, Prijana ${ }^{2}$, Samson CMS 3 \\ ${ }_{123}$ Program Studi Ilmu Perpustakaan Universitas Padjadjaran \\ Jl. Raya Bandung-Sumedang Km. 21, Jatinangor, Sumedang, Jawa Barat 45363 \\ E-mail : ${ }^{1}$ asep.saefulr@gmail.com, 2 prijanafikom@gmail.com, ${ }^{3}$ samsoncms97@gmail.com
}

Received: January 2017; Accepted: April 2018; Published: May 2018

\begin{abstract}
The Sundanese language becomes one of the regional languages in the Indonesian Dewey Decimal Classification (DDC)'s notation 499.2232. The knowledge of Sunda has become a representation of the language used by the Sunda ethnicity in ancient and present times, thus it is necessary to record the development of language science and Sundanese literature into the DDC system in the library. This study aimed to extend the Dewey's Classification notation in the field of the Sundanese language and literature. The scope of this study was to review the Indonesian and Sundanese language and literature notations in the 23rd edition of DDC Classification System, the development of knowledge about the Sundanese language and Sundanese literature, as well as the extension of the notation on the subjects. The research used a qualitative method using a descriptive. The result of this study was the extension of the Sundanese language and literature subject notation to complete the DDC classification scheme, which then would be submitted to the Library Material Development and Information Services in the National Library of Indonesia. Furthermore, the development of knowledge of the Sundanese language and literature that have been published in various forms of publication, to date can be represented by some more specific classification notation under the notation 499.2232 for the Sundanese language and under notation 899.2232 for the Sundanese literature. The notation will also provide benefits in the management of library materials as a representation of information contained in various publications on the Sundanese language and literature.
\end{abstract}

Keywords: Dewey Decimal Classification; Sundanese language; Sundanese literature; Qualitative method

\begin{abstract}
Abstrak
Bahasa Sunda menjadi salah satu bahasa daerah dalam klasifikasi Dewey Decimal Classification (DDC) bahasa Indonesia pada notasi 499.2232. Pengetahuan tentang Sunda menjadi representasi dari bahasa yang digunakan oleh etnis Sunda pada zaman dahulu kala dan sekarang yang mengalami perkembangan sehingga perlu dilakukan pencatatan pengembangan keilmuan bahasa dan susastra Sunda ke dalam sistem pengklasifikasian DDC di perpustakaan. Penelitian ini bertujuan untuk melakukan perluasan notasi Dewey Decimal Classification dalam bidang bahasa dan susastra Sunda. Ruang lingkup kajian ini adalah mengkaji notasi bahasa dan susastra Indonesia dan Sunda pada Sistem Klasifikasi DDC edisi 23, perkembangan pengetahuan tentang bahasa Sunda dan susastra Sunda, serta perluasan notasi pada subyek-subyek tersebut. Metode penelitian yang digunakan adalah metode deskriptif melalui pendekatan kualitatif. Hasil kajian ini adalah berupa perluasan notasi subyek bahasa dan susastra Sunda untuk melengkapi skema klasifikasi DDC. Hasil kajian akan disampaikan pada Bidang Pengembangan Bahan Pustaka dan Jasa Informasi di Perpustakaan Nasional Republik Indonesia. Perkembangan pengetahuan tentang bahasa dan susastra Sunda yang telah dipublikasikan dalam berbagai bentuk terbitan, hingga saat ini dapat diwakili oleh beberapa notasi klasifikasi yang lebih spesifik di bawah notasi 499.2232 untuk bahasa Sunda dan di bawah notasi 899.2232 untuk susastra Sunda. Notasi tersebut juga akan memberikan manfaat dalam pengelolaan bahan pustaka sebagai representasi informasi yang terkandung dalam berbagai terbitan tentang bahasa dan susastra Sunda.
\end{abstract}

Kata Kunci: Dewey Decimal Classification; Bahasa Sunda; Susastra Sunda; Metode kualitatif 


\section{PENDAHULUAN}

Dalam perkembangan dunia perpustakaan modern dewasa ini, sistem klasifikasi bagi penyusunan koleksi perpustakaan lebih menitikberatkan pada subyek yang dibahas dalam setiap bahan pustaka. Banyak sekali jenis skema klasifikasi yang dapat digunakan perpustakaan. Yang paling dikenal luas dan banyak digunakan di seluruh dunia ialah skema klasifikasi, "Dewey Decimal Classification (DDC), Universal Decimal Classification (UDC), dan Library of Congres Classification (LCC)" (Rotmianto, 2015). Fungsi utama dari tiap skema klasifikasi tersebut adalah untuk membimbing pemakai agar dapat memperoleh buku (bahan pustaka) yang diperlukannya dalam deretan koleksi, baik melalui pendekatan oleh pemustaka itu sendiri maupun melalui sistem pelayanan tertutup, di mana pengambilan buku (bahan pustaka) dilakukan oleh pustakawan.

Salah satu pengetahuan yang turut mengalami perkembangan yakni pengetahuan dalam bidang bahasa dan susastra Sunda. Sebagai salah satu entitas budaya yang khusus ada di wilayah Jawa Barat, Sunda merupakan salah satu etnik, ras dan suku bangsa yang diakui memiliki kekhasan dibandingkan kebudayaan lainnya. Berbagai hasil kajian, penelitian dan karya literasi khususnya dalam bahasa Sunda, termasuk karya sastra, yang dihasilkan oleh masyarakat Sunda maupun peneliti, pengkaji dan pemerhati tentang Sunda dalam era saat ini terus mengalami perkembangan dan kemajuan cukup pesat. Menurut Susanti, Mulyana, dan Damayani (2013) bahwa, "Bagi para penulis Sunda, salah satu cara yang bisa dilakukan untuk melestarikan budaya daerahnya adalah melalui tulisan".
Melalui tulisan, para penulis Sunda menyampaikan pesan dengan memanfaatkan bahasa sebagai alat komunikasi. Kerajaan dan kebudayaan Sunda pernah dianggap hilang pada beberapa abad silam, namun sejak awal abad ke-20, upaya-upaya untuk menumbuhkembangkan kembali kebudayaan Sunda terus mengalami kemajuan yang cukup berarti. Dan hal itu amat tergantung pada temuan hasil karya tulis yang ditulis para penulis Sunda maupun tentang Sunda itu sendiri.

$$
\text { Memperbaharui susunan }
$$

pengetahuan dalam DDC dapat dilakukan setiap negara di seluruh dunia. Hal tersebut umumnya dilakukan oleh Perpustakaan Nasional RI sebagai pihak yang berkepentingan dalam mengelola perkembangan pengetahuan di suatu negara. Selain itu, kalangan perguruan tinggi juga termasuk sebagai pihak yang dapat turut berkontribusi melalui kegiatan penelitian. Hasil dari kajian penelitian tentang pengembangan notasi DDC ini tentu dapat digunakan baik untuk kalangan internal di lingkungan perguruan tinggi atau dapat juga diusulkan agar menjadi konsensus nasional sehingga dapat diterapkan secara nasional di berbagai perpustakaan. Bahkan dapat juga diusulkan ke tingkat internasional melalui lembaga Online Computer Library Center (OCLC). Hal ini sesuai dengan pendapat Suherman (2016) yang menyatakan bahwa bahasa daerah dan susastra daerah perlu perluasan supaya pemustaka menemukan koleksi dengan cepat dan mudah.

Berdasarkan latar belakang masalah di atas, maka topik kajian yang telah kami laksanakan, dirumuskan sebagai berikut: “Bagaimana perluasan notasi klasifikasi tentang bahasa dan 
susastra Sunda dalam skema klasifikasi pengetahuan pada Dewey Decimal Classification (DDC)?". Adapun yang menjadi fokus dalam kajian ini adalah bagaimana analisa terhadap kondisi susunan notasi tentang bahasa dan susastra Sunda dalam skema klasifikasi Dewey, peta pengetahuan tentang keilmuan dalam bidang bahasa dan susastra Sunda, serta bagaimana perluasan notasi tentang subyek bahasa dan susastra Sunda di dalam susunan skema klasifikasi pengetahuan Dewey.

Kajian ini juga diharapkan dapat menghasilkan tujuan dan manfaat yakni berupa diperolehnya gambaran tentang susunan notasi tentang bahasa dan susastra Sunda yang ada dalam skema klasifikasi Dewey, diketahuinya peta pengetahuan tentang bahasa dan susastra Sunda sebagai bagian tak terpisahkan dalam Kebudayaan sunda, dan disusunnya perluasan notasi dalam sistem klasifikasi Dewey terkait dengan subyek pengetahuan tentang bahasa dan susastra Sunda.

Secara umum dapat dikatakan bahwa klasifikasi adalah usaha menata alam pengetahuan ke dalam tata urutan sistematis. Sulistyo-Basuki

menyebutkan, "Klasifikasi sebagai proses pengelompokan artinya mengumpulkan benda atau entitas yang sama serta memisahkan benda atau entitas yang tidak sama. Dalam pengertian lain, secara sederhana klasifikasi merupakan pengelompokan benda atau obyek lainnya berdasarkan ciri-ciri yang sama".

Skema klasifikasi yang dikenal luas di seluruh dunia yakni Klasifikasi Persepuluhan Dewey. Dewey decimal classification (DDC) merupakan skema klasifikasi perpustakaan modern yang banyak digunakan di dunia termasuk di
Indonesia. Skema klasifikasi ini disusun Melvil Dewey dari Amerika Serikat. Edisi pertama diterbitkan pada tahun 1876 dengan judul "A Clasification and Subject Index for Cataloguing and Arranging the Books and Pamphlets of a Library" (Dewey, 2011). Sedangkan edisi terakhir yang telah diterbitkan yaitu edisi 23 yang terbit pada bulan Mei 2011 lalu. Namun hingga saat ini masih banyak perpustakaan yang menggunakan DDC edisi 21 (terbit tahun 1996), edisi 22 (terbit tahun 2003) maupun edisi 23 yang terbit sejak 2011 lalu. Hal tersebut tidak menjadi suatu masalah karena edisi-edisi tersebut masih cukup relevan untuk digunakan dalam penentuan nomor klas bahan pustaka.

Prinsip dasar pembagian pengetahuan dalam DDC disebut desimal. Hal ini dikarenakan DDC membagi semua ilmu pengetahuan ke dalam 10 klas subyek utama dengan notasi 000 sampai 900. Begitulah seterusnya setiap pembagian klas diuraikan menjadi 10 bagian subyek yang lebih khusus. Dengan prinsip desimal, DDC memberikan tiga ringkasan yang menunjukkan 10 klas utama, 100 divisi dan 1000 seksi dari gambar utama. Setiap klas dari 100 sampai dengan 900 terdiri dari satu kelompok disiplin ilmu yang berhubungan. Klas 000 dicadangkan bagi bahan pustaka yang subyeknya umum.

Berdasarkan data yang ditulis oleh Mikihiro Moriyama dalam penelitiannya, yang kemudian ia tuliskan dalam buku dengan judul "Semangat Baru: Kolonialisme, Budaya Cetak dan Kesastraan Sunda Abad ke-19" tahun 2005, menyatakan bahwa:

"Pada 1872 pemerintah kolonial mengumumkan bahwa bahasa Sunda 'paling murni' dituturkan di Bandung. Bahasa Sunda dialek Bandung, bersama dengan bahasa Jawa yang dituturkan di 
Surakarta, bahasa Batak dari dialek Mandailing, dan bahasa Melayu yang dituturkan di Malaka dan kepulauan Riau, ditetapkan sebagai bahasa pengantar di sekolah-sekolah Bumiputra Belanda“ (Moriyama, 2005).

Ini cukup menjelaskan bahwa, bentuk murni bahasa Sunda adalah suatu kreasi (yang bermuatan) ideologis tertentu. Belum lagi kebijakan lainnya yang ditetapkan pemerintah kolonial pada saat itu, di antaranya penetapan aksara cacarakan Jawa yang dipilih menjadi aksara resmi pemerintahan. Sehingga akibatnya aksara lokal lainnya termasuk aksara pegon (pada saat itu merupakan aksara resmi Sunda) tidak digunakan dalam tulis-menulis pada sistem administrasi pemerintah, termasuk di sekolah. Pada tahun 1865 ibu kota Priangan di Cianjur dipindahkan ke Bandung, sehingga hal tersebut, menambah panjang pergeseran kebudayaan dan peradaban urang Sunda.

Desakan kultural aksara cacarakan dari budaya Jawa di masa lalu telah berdampak pada tenggelamnya aksara Sunda. Setelah para sarjana muslim memperkenalkan aksara Arab atau disebut aksara pegon sejak abad ke-15, jenis aksara dalam kehidupan urang Sunda menjadi bertambah. Namun aksara baru ini pun kembali tenggelam karena faktor tertentu untuk kepentingan politik penguasa pada saat itu. Hal tersebut seperti diungkapkan oleh Mikihiro Moriyama pada bukunya tersebut. Ia mengatakan,

"Aksara Arab (huruf pegon) diperkenalkan oleh para sarjana muslim sejak abad ke-15, digunakan di lingkungan institusi-institusi agama Islam. Aksara Jawa diperkenalkan sejak abad ke-17, ketika pengaruh kerajaan Mataram mulai terasa di bagian barat pulau Jawa dan kaum menak (bangsawan lokal) mengikuti teladan dalam bahasa Jawa dan aksaranya" (Moriyama, 2005).

Setelah itu, buku-buku (manuskrip) didominasi dengan aksara Arab pegon. Pada masa kolonial, aksara arab pegon dianggap sebagai suatu ancaman bagi pemerintah, sehingga kemudian urang Sunda dipaksa lagi untuk mengganti aksara resmi pemerintah dengan aksara Jawa dan Latinnya. Menurut Ekadjati (1988) dalam Moriyama (2005), dari 488 Naskah yang ada di sejumlah perpustakaan dan institusi kebudayaan di Indonesia, memperlihatkan bahwa urang Sunda pada sekitar abad-17 hingga abad ke-19 menggunakan tiga jenis aksara, yaitu Arab, Jawa dan Latin. Hal tersebut seperti diungkapkan oleh Mikihiro Moriyama dalam bukunya,

“Kemudian keputusan pemerintah Kolonial pada tahun 1852 mengenai pendidikan untuk penduduk Bumiputra menyatakan bahwa pada prinsipnya dua bahasa dan tiga aksara harus dipakai di daerah Priangan; bahasa Sunda dalam aksara Jawa dan bahasa melayu dalam aksara Arab dan latin. Dan desakan agar unsur-unsur Islam (buku pada saat itu) dijauhkan dari dunia pendidikan di tatar Priangan karena dianggap berbahaya" (Moriyama, 2005).

Tidak mengherankan bila kemudian aksara Kaganga (aksara Sunda) tidak begitu dikenal. Baru pada tahun 1990-an aksara Kaganga diketahui lebih jauh oleh para Peneliti Sastra dan Budaya Sunda dari Universitas Padjadjaran yaitu Prof. Edi S. Ekadjati dan Undang Ahmad Darsa. Fakta lain diketahui berdasarkan hasil penelitian Purnomowulan dan kawan-kawan pada tahun 2015 di Kabupaten Bandung. Temuan yang diperoleh dari sampel masyarakat di 10 kecamatan di Kabupaten Bandung, hasilnya sangat mencengangkan. 
Masyarakat yang diteliti ternyata tidak mengetahui aksara Kaganga. Saat ini baru kalangan terbatas seperti filolog, arkeolog, budayawan dan kelompok masyarakat tertentu yang mengetahui adanya aksara tersebut.

$$
\text { Dalam Darsa (2015) dijelaskan }
$$

bahwa aksara Kaganga secara tata tulis memiliki 32 abjad yang terdiri atas 7 aksara swara (vokal) dan 25 aksara ngalagena (konsonan) itu. Karya sastra Sunda dari masa paruh kedua abad ke-19, oleh para penulis Sunda telah dirumuskan cara baru dalam penulisannya. Salah seorang tokohnya adalah Moehamad Moesa (1822-1886). Karyanya yang paling berhasil adalah Wawacan Panji Wulung, diterbitkan pada tahun 1871. Buku tersebut dibaca dan diisukan oleh banyak kalangan sehingga terbukti cukup langgeng hingga memasuki abad 20. Budaya melek cetak pun menciptakan sebentuk tulisan Sunda yang baru pada masa itu.

\section{METODE PENELITIAN}

Kajian ini menerapkan metode deskriptif dengan pendekatan kualitatif. Penelitian dilakukan dengan cara mengamati dokumen/pustaka yakni berupa pustaka tentang kajian bahasa Sunda dan literatur sastra Sunda untuk memperoleh gambaran pengetahuan tentang aspek bahasa dan susastra Sunda sesuai dengan perkembangan keilmuannya terkini. Hasil pengamatan terhadap subyek tersebut kemudian dianalisa dan dilakukan pemetaan terhadap susunan pengetahuan tentang bahasa dan susastra Sunda. Tujuan penggunaan metode tersebut juga adalah untuk memperoleh data yang cukup dalam pembentukan perluasan notasi klasifikasi pada kelompok bahasa dan susastra Sunda dalam skema klasifikasi pengetahuan DDC yang ada.

Pendekatan kualitatif sendiri merupakan suatu pendekatan dalam melakukan penelitian atau suatu kajian yang berorientasi pada gejala-gejala yang bersifat alamiah. Karena orientasinya demikian, maka sifatnya naturalistik dan mendasar atau bersifat kealamiahan serta tidak bisa dilakukan di laboratorium melainkan harus terjun di lapangan (Nazir, 2011). Peneliti melakukan studi melalui diskusi terpumpun serta pengamatan terhadap perkembangan literatur tentang bahasa dan susastra Sunda di perpustakaan umum maupun perpustakaan perguruan tinggi.

\section{HASIL DAN PEMBAHASAN}

Seperti kita ketahui bahwa DDC adalah merupakan skema klasifikasi yang terdiri dari susunan berbagai kelompok pengetahuan, di mana melalui DDC kita dapat melakukan penentuan kategori/pengelompokkan pengetahuan suatu subyek yang menjadi topik bahasan dalam setiap bahan pustaka. Terkait dengan golongan subyek bahasa dan susastra yang terdapat dalam DDC, kelompok pengetahuan tentang Bahasa dan Susastra umumnya masih ditentukan berdasarkan bahasa-bahasa dan kesusastraan dari negara-negara tertentu saja. Hal tersebut dapat dilihat pada ringkasan di gambar 1.

400 Bahasa

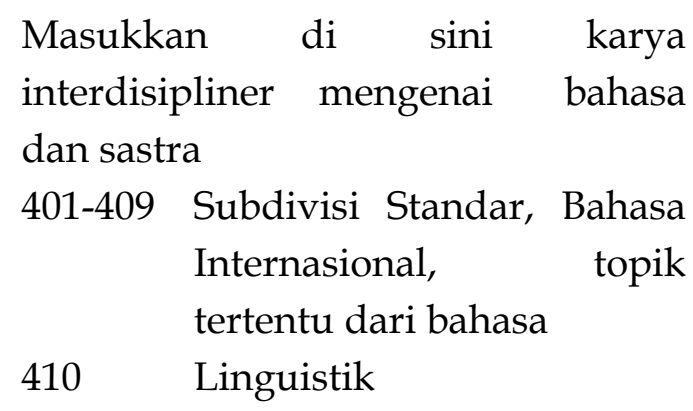




\begin{tabular}{|c|c|}
\hline 420 & $\begin{array}{l}\text { Bahasa Inggris dan Inggris } \\
\text { Purba (Anglo Saxon) }\end{array}$ \\
\hline 430 & $\begin{array}{l}\text { Bahasa Jerman dan bahasa } \\
\text { yang berkaitan }\end{array}$ \\
\hline 440 & $\begin{array}{llr}\text { Bahasa } & \text { Perancis dan } \\
\text { Bahasa } & \text { Roman yang } \\
\text { berkaitan } & & \end{array}$ \\
\hline 450 & $\begin{array}{l}\text { Bahasa Italia, Dalmatia, } \\
\text { Romania, } \\
\text { Sardinia, Korsika }\end{array}$ \\
\hline 460 & $\begin{array}{l}\text { Bahasa Spanyol, Portugis, } \\
\text { Galician }\end{array}$ \\
\hline 470 & $\begin{array}{l}\text { Bahasa Latin dan Bahasa } \\
\text { Italik yang berkaitan }\end{array}$ \\
\hline 480 & $\begin{array}{l}\text { Bahasa Yunani Klasik dan } \\
\text { Bahasa Helenik yang } \\
\text { berkaitan }\end{array}$ \\
\hline 490 & Bahasa lainnya \\
\hline
\end{tabular}

Gambar 1. Klasifikasi Klas Utama Bahasa (400) DDC edisi 23

Sumber: OCLC dalam Perpustakaan Nasional RI, 2013

Nampak dalam ringkasan di atas bahwa kategorisasi pengetahuan tentang bahasa masih didominasi oleh negaranegara Eropa. Jika ditelusuri lebih lanjut, Bahasa Indonesia terdapat pada notasi Klas Divisi 490, yakni tepatnya pada Notasi Klas Seksi 499.221. Notasi tersebut kemudian oleh Perpustakaan Nasional RI melalui Bidang Pengembangan Bahan Pustaka dan Jasa Informasi dikembangkan sedemikian rupa sehingga susunannya dapat kita lihat seperti gambar 2 .

499.221 Bahasa Indonesia

Masukkan di sini karya komprehensif mengenai Bahasa Indonesia

Kecuali bila ada modifikasi sebagaimana ditunjukkan pada entri tertentu, maka tambahkan pada angka dasar 499.221 notasi
01 - 8 dari Tabel 4, misal tata bahasa Indonesia 499.2215

499.221 1 Sistem Tulisan, Fonologi, Fonetik

Bahasa Indonesia Baku

499.221 2 Etimologi Bahasa Indonesia

Baku

499.221 3 Kamus Bahasa Indonesia Baku

[499.221 4] [Tidak Digunakan]

499.221 5 Tata Bahasa Indonesia

[499.221 6] [Tidak Digunakan]

499.221 7 Variasi historis dan geografis, variasi nongeografis modern bahasa Indonesia

.001 - .008 Subdivisi standar

.009 Aspek historis, geografis, manusia

499.221 8 Pemakaian bahasa Indonesia baku (linguistik preskriptif Bahasa-Bahasa Daerah di Indonesia)

499.222 Bahasa Jawa Termasuk Bahasa Betawi

499.223 Bahasa-bahasa MalayoPolynesia di Jawa dan Bali

2 Bahasa Sunda

4 Bahasa Madura

8 Bahasa Bali

499.224 Bahasa-bahasa MalayoPolynesia di Sumatra 2 Bahasa Aceh

4 Bahasa Minangkabau

6 Bahasa-Bahasa Batak

Termasuk bahasa Mandailing, Simalungun, Karo

62 Bahasa Toba

66 Bahasa Dairi

8 Bahasa Lampung

499.225 Bahasa-bahasa MalayoPolynesia di Kalimantan

6 Bahasa Banjar

499.226 Bahasa-bahasa MalayoPolynesia di Sulawesi

2 Bahasa Bugis

4 Bahasa Makasar 
499.227

Bahasa-bahasa

Malayo-

Polynesia di Maluku Selatan, Nusa Tenggara

499.5 Bahasa-bahasa di Papua

Gambar 2. Klasifikasi Klas Bahasa Indonesia

Sumber: Perpustakaan Nasional RI, 2013

Dalam susunan klasifikasi bahasa Indonesia di atas, dilihat betapa kayanya bahasa Indonesia baik dilihat dari aspek sistem ketatabahasaan hingga pembagiannya ke dalam berbagai bahasa daerah yang ada di nusantara. Salah satu bahasa daerah yang diakui dan mendapatkan tempat tersendiri secara kokoh yakni bahasa Sunda pada notasi 499.2232. Bahasa Sunda dalam susunan klasifikasi telah terdaftar pada DDC sejak beberapa edisi lalu. Dapat kita perhatikan bahwa bahasa Sunda bukan merupakan bagian dari bahasa daerah tertentu seperti halnya kita lihat pada susunan di atas, misalnya bahasa Betawi sebagai bagian dari notasi bahasa Jawa. Atau bahasa Mandailing, Simalungun dan Karo sebagai bagian dari bahasa Batak.

Selanjutnya kita lihat bagaimana pengetahuan tentang kesusastraan dalam susunan skema klasifikasi DDC, yakni pada klas utama 800. Seperti halnya dengan susunan klasifikasi bahasa, subyek pengetahuan kesusastraan pun umumnya disusun berdasarkan urutan negaranegara yang paling dikenal di dunia. Dapat dipahami bahwa negara-negara tersebut sangat terkenal dengan kekayaan karya susastra yang dihasilkan oleh para sastrawannya yang dikenal populer di dunia. Adapun gambar klasifikasi kesusastraan dapat kita lihat dari susunan klas utama dari klas utama 800 di gambar 3.
800

Kesusastraan (Belles-Letters) dan Retorika

Masukkan disini karya

kesusastraan, karya tentang kesusastraan.

801-807 Subdivisi Standar

808 Retorika dan kumpulan teks literer lebih dari dua bentuk kesusastraan

809 Sejarah, deskripsi, kritik lebih dari karya sastra atau lebih

810 Kesusastraan Amerika dalam bahasa Inggris

820 Kesusastraan Inggris dan Inggris Kuno (anglosaxon)

830 Kesusastraan Jermania dan kesusastraan yang berkaitan dengan kebahasaan

840 Kesusastraan Perancis dan kesusastraan yang berkaitan dengan bahasa Roman

850 Kesusastraan Italia, Dalmatia, Roman, Rhaetia Sardinia, Kesusastraan Korsican

860 Kesusastraan Spanyol, Portugis Bahasa Galician

870 Kesusastraan Latin dan kesusastraan yang berkaitan dengan bahasa Latin

880 Kesusastraan Yunani Klasik dan kesusastraan yang berkaitan dengan bahasa-bahasa Hellenic

890 Sastra dari rumpun bahasa dan bahasa spesifik lainnya

Gambar 3. Klasifikasi Klas Kesusatraan Sumber: OCLC dalam Perpustakaan Nasional RI, 2013

Dalam gambar klasifikasi di atas, kita belum dapat melihat di mana notasi klasifikasi susastra Indonesia. Di antara susunan klas divisi 810-890 tersebut tentunya kesusastraan Indonesia paling memungkinkan dapat kita telusuri dari klas divisi 890 (Sastra dari rumpun bahasa 
dan bahasa spesifik lainnya). Kemudian khusus untuk Kesusastraan Indonesia terdapat pada Klas Seksi 899.221. Hal tersebut dapat kita lihat pada susunan gambar 4.

899.221 Kesusastraan Indonesia

Tambahkan pada angka dasar $899.221 \quad 1-899.221 \quad 8$ Notasi $\quad-1-8$ dari Tabel 3

Tabel Periode untuk Kesusastraan Indonesia

1 Periode awal

2 sampai 1899

3 1900-1999

$42000-$

899.221 1 Puisi Indonesia

899.221 2 Drama Indonesia

899.221 3 Fiksi Indonesia

899.221 4 Esai Indonesia

899.221 5 Pidato Indonesia

899.221 6 Surat-Surat Indonesia

899.221 7 Humor dan Satire Indonesia

899.221 8 Bunga Rampai Indonesia

Kesusastraan Daerah di Indonesia

899.222 Kesusastraan Jawa

Termasuk Kesusastraan Betawi

899.223 Kesusastraan Malayo-Polynesia di Jawa dan Bali

2 Kesusastraan Sunda

4 Kesusastraan Madura

8 Kesusastraan Bali

899.224 Kesusastraan Malayo-Polynesia di Sumatra

2 Kesusastraan Aceh

4 Kesusastraan Minangkabau

6 Kesusastraan Bahasa Batak

62 Kesusastraan Toba

66 Kesusastraan Dairi

8 Kesusastraan Lampung

899.225 Kesusastraan Malayo-Polynesia di Kalimantan

6 Kesusastraan Banjar

899.226 Kesusastraan Malayo-Polynesia di Sulawesi
2 Kesusastraan Bugis

4 Kesusastraan Makasar

899.227 Kesusastraan Malayo-Polynesia di Maluku Selatan, Nusa Tenggara

899.5 Kesusastraan di Papua

Gambar 4. Klasifikasi Klas Kesusastraan Indonesia

Sumber: Perpustakaan Nasional RI, 2013

Dengan melihat susunan gambar klasifikasi tentang kesusastraan Indonesia dan daerah di atas, maka kita dapat dengan mudah menentukan suatu notasi dari berbagai bentuk karya sastra Indonesia mulai dari bentuk puisi, drama hingga humor, satire dan bunga rampai yang ditulis oleh para sastrawan/pujangga Indonesia. Tidak hanya itu, berbagai kesusastraan daerah pun sudah dapat terakomodir oleh susunan notasi klasifikasi DDC yang telah dikembangkan susunannya oleh Perpustakaan Nasional RI tersebut. Termasuk dalam hal ini juga kesusastraan Sunda sebagai salah satu kesusastraan daerah di Indonesia.

Berdasarkan hasil diskusi terpumpun (FGD) bersama para pakar bahasa dari akademisi Program Studi Bahasa dan Sastra Sunda di Universitas Padjadjaran bahwa bahasa dan susastra merupakan salah unsur-unsur dalam kebudayaan di antara ketujuh unsur kebudayaan yang ada di dunia.

"Bahasa merupakan penciri khas suatu bangsa/suku bangsa. Kita dapat membedakan suku Batak dengan suku Jawa secara mudah dengan memperhatikan bahasa yang digunakan oleh kedua suku tersebut. Begitu pula dengan bahasa dan susastra Sunda, ia memiliki ciri khas yang amat jelas jika dibandingkan dengan bahasa dan susastra daerah 
lain di Indonesia" (M. Ruhimat, wawancara, Oktober 3, 2016).

Koentjaraningrat

berpendapat bahwa ada tujuh unsur kebudayaan yang dapat ditemui pada semua bangsa di dunia. Ketujuh unsur itu adalah unsur bahasa, sistem pengetahuan, organisasi sosial, sistem peralatan hidup dan teknologi, sistem mata pencaharian, sistem religi dan kesenian. Setiap unsur kebudayaan tersebut dapat diwujudkan ke dalam tiga wujud kebudayaan berupa sistem budaya, sistem sosial, dan berupa unsur kebudayaan fisik. Salah satu unsur yang paling penting dalam melihat suatu etnis/suku bangsa yakni unsur sistem pengetahuannya. Pengetahuan yang ditemukan dan berkembang pada suatu etnis/suku bangsa merupakan perwujudan dari penggunaan bahasa yang digunakan baik untuk memahami maupun untuk menjelaskan segala sesuatu.

Berbicara mengenai pengetahuan yang berkembang atau dikembangkan pada/oleh masyarakat Sunda dan tentang etnis/masyarakat Sunda sudah sedemikian banyaknya. Pengetahuan tentang sunda telah ada sejak masyarakat sunda terbentuk dan sejak ditemukannnya aksara Sunda sebagai representasi dari bahasa yang digunakan oleh etnis Sunda pada zaman dahulu kala. Hal tersebut disampaikan dalam Diskusi Terpumpun yang dilaksanakan dalam Kajian ini pada Oktober 2016 di Unpad.

"Kita mengenal adanya huruf Kaganga sebagai aksara Sunda kuno setelah kita semua sempat mengakui bahwa aksara Sunda adalah Hanacaraka atau Cacarakan sebagai adopsi dari aksara Jawa Kuno" (M. Ruhimat, wawancara, Oktober 3, 2016).
Sedangkan pendapat lain berkata, "Seiring dengan perkembangan masyarakat dan etnis Sunda di Tatar Sunda, maka berbagai pengetahuan terkait kebahasaan Sunda terus diciptakan oleh Urang Sunda" (M. Ruhimat, wawancara, Oktober 3, 2016).

Pengetahuan yang ada dalam pikiran (Tacit) kemudian diucapkan/ disampaikan kepada manusia lainnya. Namun ucapan secara lisan tidak dapat diduplikasi secara persis oleh manusia lain yang menyampaikannya. Oleh karena itu manusia perlu alat bantu yakni berupa tulisan maupun rekaman sebagai representasi dari lisan yang diucapkan, di mana lisan sendiri merupakan hasil dari proses pemikiran dan perasaannya. Tulisan merupakan simbol dari bahasa lisan yang disepakati dan digunakan oleh umat manusia. Dengan adanya tulisan maka pengetahuan yang tadinya tacit, kemudian dapat berwujud (eksplisit) serta dapat disebarluaskan kepada khalayak. Urang Sunda pernah menggunakan Cacarakan sebagai simbol dari bahasa lisan yang digunakan. Namun urang Sunda sendiri ternyata memiliki aksara kuno (Sunda buhun) yang berbeda sama sekali dari Cacarakan yang berasal dari aksara Jawi kuno.

Pengetahuan yang dimiliki oleh urang Sunda kemudian banyak yang dituliskan menggunakan aksara, baik Cacarakan maupun Kaganga tadi. Kemudian ketika penjajahan Belanda, banyak juga kemudian pengetahuan urang Sunda maupun tentang Sunda yang dituliskan menggunakan aksara latin. Pengetahuan tentang Sunda maupun urang Sunda kemudian semakin mendunia. Maka, "kajian atau pengetahuan tentang bahasa Sunda dapat dibagi menjadi dua, yakni tentang bahasa 
Sunda baku dan bahasa Sunda dialek" (M. Ruhimat, wawancara, Oktober 3, 2016). Masing-masing dapat dirinci/dibagi lagi menjadi beberapa kajian/pengetahuan.

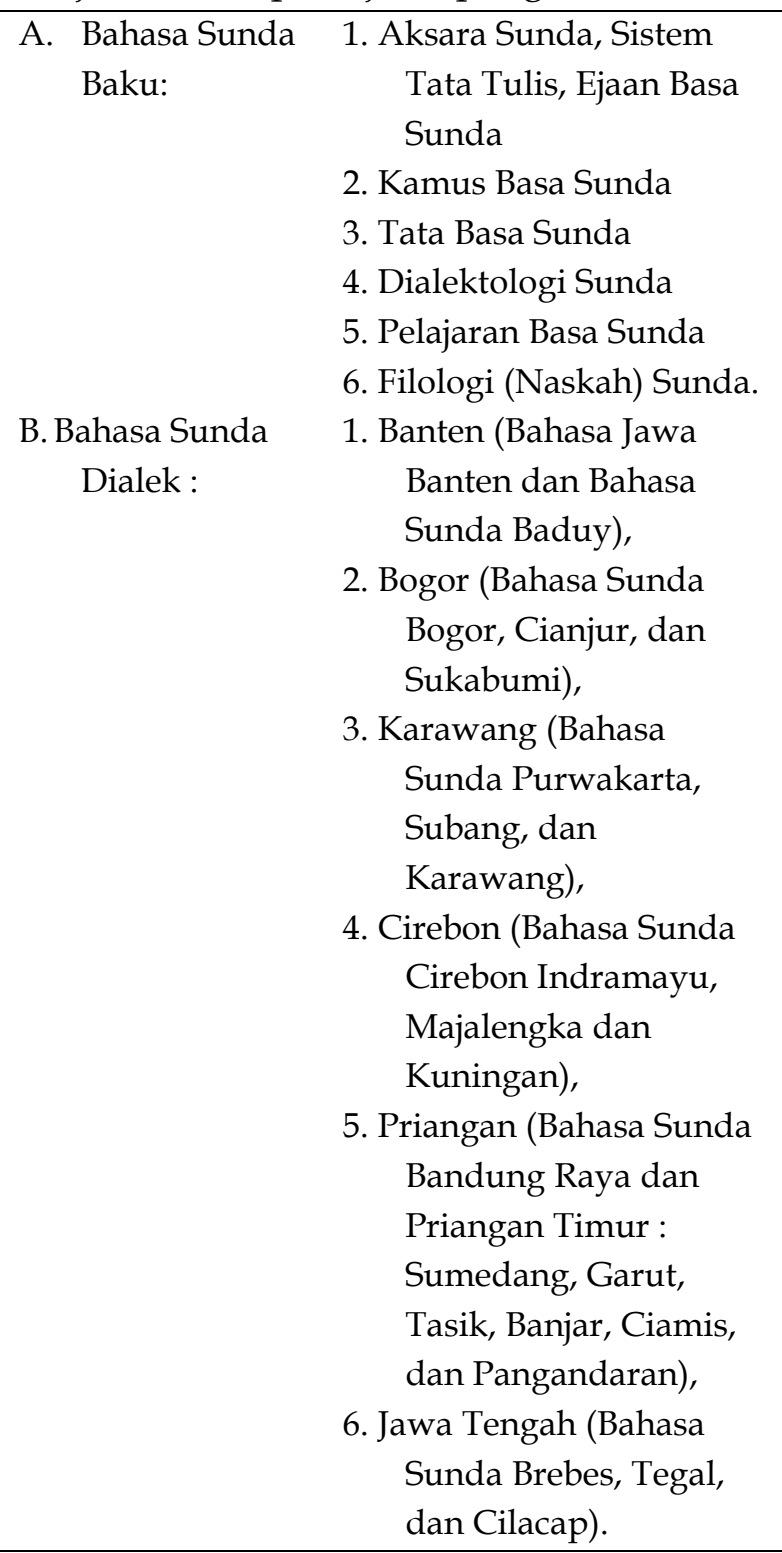

Selain aspek bahasa, pengetahuan kasundaan juga banyak dalam bentuk karya sastra. Hal tersebut sering dikaitkan dengan bahasa Sunda sebagai bahasa rasa sehingga dengan bahasa Sunda, banyak juga urang Sunda yang kemudian melahirkan berbagai susastra Sunda. Karenanya kajian tentang susastra sendiri tidak dapat dipisahkan dari kajian tentang aspek kebahasaannya itu sendiri. Dalam hal ini susastra Sunda umumnya menggunakan bahasa Sunda sebagai bahasa tuturnya, baik secara lisan maupun tertulis. Berdasarkan hasil FGD diuraikan kajian mengenai susastra Sunda.

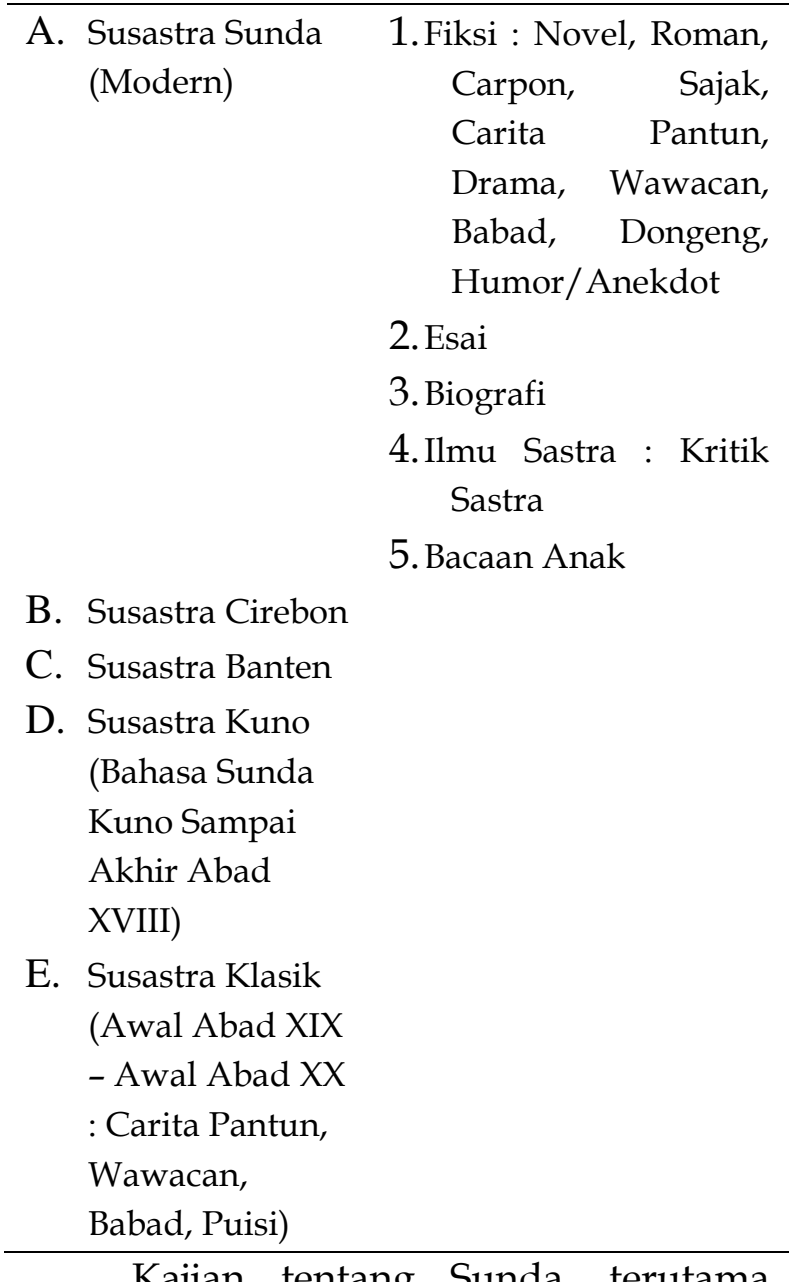

Kajian tentang Sunda, terutama kaitannya dengan bahasa Sunda baku maupun susastra Sunda, saat ini merupakan bagian tak terpisahkan dari pendidikan tinggi dalam bidang bahasa dan susastra Sunda, termasuk kajian tentang budaya Sunda.

"Karena bahasa dan susastra merupakan bagian atau unsur dalam kebudayaan manusia, tidak terkecuali dalam konteks Sunda sebagai sebuah etnis" (R. Sopyan, wawancara, Oktober 3, 2016).

Lebih lanjut dikatakan bahwa,

“Berbagai hasil kajian menyangkut aspek kebahasaan Sunda, baik tentang aksara, tata tulis dan tata basa, ejaan, pelajaran basa sunda, dialektologi hingga tentang kajian naskah kuno masyarakat Sunda sebagai warisan budaya dan pengetahuan, terus dilakukan hingga 
saat ini. Termasuk juga berbagai hasil penciptaan berbagai jenis dan bentuk karya susastra Sunda" (R. Sopyan, wawancara, Oktober, 3, 2018).

Berbicara mengenai kajian, maka wujud nyata dari hasilnya dapat berupa pustaka dalam bentuk buku, majalah, jurnal ilmiah, laporan penelitian, karya ilmiah, artikel atau esai di surat kabar, kamus bahasa, kamus istilah, ensiklopedia, panduan, buku saku, poster, dan berbagai bentuk sajian karya sastra seperti kumpulan cerpen, cerita rakyat, novel, dongeng, sajak dan puisi juga pupuh. Termasuk juga pustaka dalam bentuk elektronik seperti kaset, compact disc, digital video disc, photo, file computer, termasuk new media berupa situs/web, blog, dan media sosial.

Notasi klasifikasi untuk subyek bahasa dan susastra, dengan cukup jelas telah dijelaskan pada bagian awal dari bab ini. Kita dapat melihat bahwa notasi bahasa dan susastra baik Indonesia maupun Sunda, terdapat dalam susunansusunan terakhir/paling belakang dari golongan 400 tentang bahasa dan 800 tentang susastra. Sebagai Bangsa Indonesia tentu harus berbangga bahwa kekayaan pengetahuan lokal tentang Indonesia, khususnya tentang bahasa dan susastra Indonesia dan daerah di nusantara telah mendapatkan tempat dalam susunan sistem klasifikasi Dewey yang dikenal luas di seluruh dunia. Bahkan pada edisi 23, notasi bahasa dan susastra sudah jauh lebih lengkap jika dibandingkan dengan edisi sebelumnya.

Dengan menggunakan acuan perluasan notasi dalam "Pedoman Klasifikasi Bahasa dan Kesusastraan Indonesia Menurut DDC edisi 23", terbitan Perpustakaan Nasional RI tahun 2013 lalu, serta mengacu pada ketentuan yang ada dalam Dewey Decimal Classification (DDC) edisi 23 terbitan OCLC tahun 2011, dapat disusun suatu perluasan notasi bahasa dan susastra Sunda di gambar 5 .

a) Perluasan Notasi Bahasa Sunda

499.2232 Bahasa Sunda

Masukkan di sini karya komprehensif mengenai bahasa Sunda. Bila modifikasi sebagaimana ditunjukkan pada entri tertentu, maka tambahkan pada angka dasar 499.2232 notasi 01 - 8 dari Tabel 4 .

499.223 21 Sistem Penulisan, Ejaan dan Aksara Sunda Baku (termasuk aksara Sunda Kaganga).

499.223 22 Etimologi Bahasa Sunda Baku

499.223 23 Kamus Bahasa Sunda Baku

499.223 25 Tata Bahasa Sunda Baku, Pelajaran Bahasa Sunda

499.223 27 Variasi Sejarah dan Geografi, Variasi NonGeografis Modern Bahasa Sunda (termasuk Dialektologi, Filologi/

Naskah Bahasa Sunda Kuno)

499.223 28 Pemakaian Bahasa Sunda Baku

499.2232 Bahasa Sunda Dialek

4 Bahasa Sunda Dialek Priangan

(termasuk Bahasa Sunda Bandung Raya dan Priangan Timur: Sumedang, Garut, Tasik, Banjar, Ciamis, dan Pangandaran)

6 Bahasa Sunda Dialek Non-

Priangan 
(termasuk Bahasa

Sunda Banten,

Bogor, Karawang,

Cirebon dan Dialek

Bahasa Sunda di

sebagian wilayah

Jawa Tengah

bagian barat)

Gambar 5. Perluasan Notasi Bahasa Sunda

Sumber: Hasil penelitian, 2016

Perluasan notasi pada notasi klasifikasi bahasa Sunda sesuai susunan yang ada pada DDC edisi 23 di atas tentu masih bersifat rancangan yang masih diperlukan kajian lebih lanjut baik dari aspek pengetahuan bahasa Sunda maupun dialek (bahasa tutur) bahasa Sunda yang ada di Jawa Barat maupun Jawa Tengah. Diperlukan kajian lebih lanjut mengenai hal tersebut. Pertimbangan efisiensi bentukan notasi dilakukan mengingat jangan sampai notasi yang disusun jangan sampai terlampau panjang.

Kemudian perlu dilakukan juga konsultasi dan koordinasi lebih lanjut mengenai susunan notasi baik notasi modifikasi antara notasi dasar dengan notasi tambahan dari Tabel 4 tentang Subdivisi Bahasa. Konsultasi dan koordinasi yang dimaksud yakni dengan pihak Perpustakaan Nasional RI, khususnya Bidang Pengembangan Bahan Pustaka dan Jasa Informasi. Sehingga pembentukan perluasan notasi ini dapat lebih dipertanggungjawabkan sesuai standar ketentuan klasifikasi Dewey.

b) Perluasan Notasi Kesusastraan Sunda 899.223 2 Kesusastraan Sunda Tambahkan pada angka dasar 899.2232 notasi -1 -8 dari Tabel 3 Tabel periode untuk Sunda
(Kesusastraan Sunda)

1 Periode awal sampai 1799

(Sastra Sunda

Kuno)

21800 - 1999 (Sastra

Sunda Klasik)

32000 (Sastra Sunda

Modern)

899.223 21 Puisi Sunda (termasuk:

Sajak, Pupuh, Wawacan, Biografi)

899.223 22 Drama Sunda (termasuk Carita Pantun)

899.223 23 Fiksi Sunda (termasuk

Novel, Roman, Cerita

Pendek, Babad,

Dongeng, Bacaan

Anak,

Fiksi Biografi)

899.223 24 Esai Sunda

899.22325 Pidato Sunda

899.22326 Surat-Surat (Serat) Sunda

899.223 27 Humor, Satire, Anekdot

Sunda

899.223 28 Bunga Rampai Sunda

(termasuk Kritik Sastra Sunda)

899.223 2 Kesusastraan Sunda

Wilayah

93 Kesusastraan

Sunda

Cirebon

94 Kesusastraan

Sunda

Banten

Gambar 6. Perluasan Notasi Kesusastraan Sunda Sumber: Hasil penelitian, 2016

Notasi kesusastraan Sunda (899.223 2 -18) di atas merupakan modifikasi antara notasi dasar dari kesusastraan Sunda dengan Notasi Tambahan dari Tabel 3 (Bentuk Sastra). Selain itu juga dilakukan 
perluasan untuk kesusastraan Sunda yang banyak dihasilkan di wilayah Cirebon dan Banten. Notasi perluasannya pun menyesuaikan dengan notasi yang tersedia untuk dimungkinkan dilakukan perluasan yang diperoleh dari Tabel 3.

Upaya modifikasi dan perluasan di atas tentu masih bersifat rancangan yang masih perlu dilakukan kajian lebih lanjut dengan lebih memperhatikan perkembangan kesusastraan Sunda dari masa ke masa, perkembangan bentuk sajian karya sastra yang berkembang pada masyarakat Sunda, serta identifikasi lebih dalam tentang wilayah-wilayah di Jawa Barat yang berpotensi menghasilkan berbagai karya sastra Sunda (selain Cirebon dan Banten).

\section{SIMPULAN}

Berdasarkan hasil kajian yang telah dilaksanakan, maka dapat ditarik beberapa simpulan. Notasi bahasa dan kesusatraan Indonesia dalam sistem klasifikasi DDC edisi 23 yang merupakan edisi terkini telah disusun dan diakomodasi lebih baik. Notasi bahasa Indonesia tidak hanya terdapat satu notasi saja di bawah susunan Klas Sub Seksi 499 yakni pada notasi 499.221 Bahasa Indonesia, namun di bawah notasi tersebut telah terdapat beberapa notasi baru untuk bahasa daerah yang ada di Indonesia yakni mulai notasi 499.222 Bahasa Jawa hingga notasi 499.2264 Bahasa Makasar. Bahasa Sunda ada pada notasi 499.2232. Notasi Kesusastraan Indonesia pun tidak hanya terdapat satu notasi saja yakni 899.221 Kesusastraan Indonesia, namun pada DDC edisi 23 telah diberikan penjelasan periode kesusastraan dan beberapa notasi kesusastraan daerah mulai dari notasi 899.222 Kesusastraan Jawa hingga notasi 899.2264 Kesusastraan
Makasar. Sedangkan Kesusastraan Sunda ada pada notasi 899.2232. Dalam hal ini bahwa notasi klasifikasi Dewey telah mengakomodir perluasan notasi bahasa dan kesusastraan yang ada di Indonesia untuk beberapa daerah sesuai dengan etnis atau suku bangsa yang memiliki kekhasan bahasa dan karya sastra, tidak terkecuali untuk bahasa dan susastra Sunda.

Peta pengetahuan bahasa dan susastra Sunda yang ada hingga saat ini merupakan hasil dari kajian keilmuan terutama di perguruan tinggi (universitas) yang menyelenggarakan Program Studi Bahasa dan Susastra Sunda seperti di Universitas Padjadjaran maupun perguruan tinggi lain, serta berbagai lembaga kajian bahasa Sunda, terutama yang ada di Jawa Barat. Berbagai karya pengetahuan terkait bahasa dan susastra Sunda telah dapat diidentifikasi dan dikategorisasikan oleh para pakar/akademisi di bidang bahasa dan susastra Sunda. Bahasa Sunda berkembang sedemikian rupa serta dapat dilihat dari berbagai aspek seperti sistem penulisan, ejaan, aksara (Arab/pegon, Cacarakan, Latin dan Kaganga), tata bahasa, etimologi, kamus, pelajaran basa Sunda, sejarah, dialektologi, filologi/naskah hingga pemakaian bahasa Sunda dalam masyarakat Sunda. Bahasa Sunda juga mengalami perkembangan dan terdapat berbagai perbedaan pada berbagai wilayah di Jawa Barat. Demikian pula dengan kesusastraan Sunda, di mana peta pengetahuan terkait karya sastra Sunda juga dapat dilihat dari berbagai periode kesusastraan seperti halnya pada susastra Indonesia. Selain itu, susastra Sunda pun dapat dilihat dari berbagai bentuk karya seperti sajak, pupuh, wawacan, biografi, carita pantun, novel, 
roman, cerita pendek, babad, dongeng, bacaan anak, esai, pidato, surat/serat Sunda, humor, anekdot, kritik dan bunga rampai Sunda. Susastra Sunda juga dapat dilihat dari wilayah-wilayah di Jawa Barat yang diidentifikasi memiliki berbagai karya sastra Sunda yang memiliki kekhasan serta dapat dibedakan dari karya sastra Sunda baku pada umumnya. Susastra Sunda tersebut terdiri dari kesusastraan Sunda di wilayah Cirebon dan di wilayah masyarakat Sunda Banten.

Perluasan notasi bahasa dan susastra Sunda disusun dengan memperhatikan susunan notasi yang telah ada pada sistem klasifikasi DDC edisi 23 dan Pedoman Klasifikasi Bahasa dan Kesusastraan Indonesia Menurut DDC edisi 23 yang telah diterbitkan oleh Perpustakaan Nasional RI pada tahun 2013 lalu. Susunan notasi bahasa Sunda disusun dengan mengikuti kaidah pada DDC edisi 23 khususnya dari Tabel Subdivisi Bahasa untuk perluasan aspek-aspek kebahasaan yakni dengan membentuk notasi 499.2232 01 -8 dari Tabel 4 dan Notasi 499.22324 untuk Bahasa Sunda Dialek Priangan dan notasi 499.223 26 untuk Bahasa Sunda Dialek Nonpriangan. Sedangkan perluasan Notasi Susastra Sunda dibentuk dengan memperhatikan jenis/bentuk karya sastra sesuai dengan petunjuk yang ada pada Tabel 3 DDC edisi 23. Notasi susastra Sunda disusun dari mulai notasi 899.2232 -1-8 dari Tabel 3. Periodisasi kesusastraan Sunda dibagi menjadi 3 Periode yakni Periode awal hingga tahun 1799 (Sastra Sunda Kuno), Periode Sastra Sunda Klasik dari tahun 1800 - 1999, dan Periode Sastra Sunda Modern dari tahun 2000 hingga saat ini dan ke depan. Notasi susastra Sunda 899.223 2 dari DDC edisi 23 juga diikuti oleh dua notasi di bawahnya berdasarkan karya kesusastraan masyarakat di wilayah Cirebon pada notasi 899.223293 dan karya kesusastraan masyarakat di wilayah Banten pada notasi 899.223294.

Untuk selanjutnya, kiranya hasil kajian ini dapat dibahas lebih lanjut baik di Program Studi Ilmu Perpustakaan Universitas Padjadjaran, maupun diantara para pakar bidang klasifikasi dari berbagai perguruan tinggi agar dapat disempurnakan hasilnya dengan lebih baik.

Kiranya dapat dilakukan pembahasan mengenai penerapan notasi dari hasil kajian ini bersama dengan pihak dari Dinas Perpustakaan Daerah Provinsi Jawa Barat maupun Perpustakaan Nasional RI. Selanjutnya dapat ditindaklanjuti dengan sebuah usulan perluasan notasi Bahasa dan Kesusastraan Sunda ke dalam Sistem Klasifikasi Dewey pada edisi selanjutnya.

\section{DAFTAR PUSTAKA}

Darsa, U. A. (2015). Kodikologi: dinamika identifikasi, inventarisasi dan dokumentasi tradisi pernaskahan Sunda. Bandung: FIB UNPAD.

Dewey, M. (2011). Dewey decimal classification (23rd ed.). Dublin Ohio: OCLC Inc.

Koentjaraningrat. (2002). Pengantar ilmu antropologi. Jakarta: Rineka Cipta.

Moriyama, M. (2005). Semangat baru: kolonialisme, budaya cetak dan kesastraan Sunda abad ke-19. Jakarta: Gramedia Pustaka Utama.

Nazir, M. (2011). Metode penelitian. Bogor: Ghalia Indonesia.

Perpustakaan Nasional RI. (2013). Pedoman klasifikasi bahasa dan kesusastraan Indonesia menurut DDC edisi 23. Jakarta: Perpustakaan Nasional RI.

Rotmianto, M. (2015). Mencermati nomor- 
nomor opsional (Optional Number) dalam sistem klasifikasi persepuluhan Dewey edisi 23 (DDC edition 23). RECORD AND LIBRARY JOURNAL, 1(1), 48-58. Retrieved from http:/ / download.portalgaruda.org/a rticle.php?article $=468108 \& \mathrm{val}=7410 \& \mathrm{t}$ itle=Observing Optional Number in DDC Edition 23

Suherman. (2016). Adaptasi dan perluasan Dewey Decimal Classification (DDC) untuk notasi (Subjek) Indonesia. LIBRIA, 8(2), 211-223. Retrieved from https://jurnal.ar- raniry.ac.id/index.php/libria/article /download/1212/907

Sulistyo-Basuki. (2014). Senarai pemikiran Sulistyo Basuki: profesor pertama ilmu perpustakaan dan informasi di Indonesia. Jakarta: Ikatan Sarjana Ilmu Perpustakaan dan Informasi Indonesia.

Susanti, S.; Mulyana, D. \& Damayani, N. A. (2013). Penulis sunda sebagai pelestari budaya. Kajian Informasi $\mathcal{E}$ Perpustakaan, 1(2), 1-26. https://doi.org/https://doi.org/10.2 4198/jkip.v1i2.11046.g4947 
